\title{
Some Issues in Translating Russian Poetry INTO English
}

\begin{abstract}
ver time there have been many marvelous translations of Russian poetry into English. At the same time, translating poetry from or into any language is never a simple thing, and there is no single correct way to do it, though individual translators may have strong feelings (and that is all to the good). Russian and English poetry offer a special case for the study of translation: they are similar in many ways - much more so than many possible translational pairs-but their different historical development and the different prosodic structures of the two languages (naturally reflected in the poetry) complicate a translator's choices interestingly. It is no surprise that various translations of the same poem can look quite dissimilar.
\end{abstract}

\section{Different Literary Histories}

The different histories of Russian literature and English literature (meaning literature written in those languages, whether or not by authors who were themselves ethnically Russian or English) have led to different results. The tradition of English poetry is today generally traced back to Geoffrey Chaucer, and so has been developing along that path since the fourteenth century (very roughly speaking), with occasional important influences from earlier works, such as Beowulf. By the twentieth century, when Modernism made a decisive break with traditional rhyme, meter, and poetic genres, English poetry had been chugging along for six centuries. Modern Russian poetry (as opposed to the earlier, 
unrhymed epics such as the twelth-century Lay of Igor's Campaign or the first appearance of rhyme in Simeon Polotsky's seventeenth-century virshy) got going in the eighteenth century, and by the Silver Age (when, we would argue, it was brought completely up to date with the rest of Europe) it had been going for about two centuries. The poems people still really read, though, dated from a mere 120 or 130 years before the Silver Age (Derzhavin, Batyushkov, Zhukovsky). Both English and Russian poetry were decisively shaped by other literary traditions, though Russian readers, writers, and scholars generally do a better job of remembering this. Most of Chaucer's works were translations, and Elizabethan poets kept busy adapting poetic genres from Italian or French to their own language. (Indeed, French literature, as Russians came to know it, was decisively formed in the seventeenth and eighteenth centuries: Ronsard looks very different from Corneille and Racine.) Modern Russian poetry stuttered to life by imitating the form of Polish wierszy, then got on track with Lomonosov's recommendation of syllabo-tonic verse (that is, verse with both regular stress patterns and a regular number of feet per line), with various rhyme schemes. Like French poetry, which incorporated many of the lessons of Neoclassicism, Russian poetry used terms from Classical Antiquity, reformulated by Boileau (Nicolas Boileau-Despréaux) in L'Art poétique (1674), a treatise on verse that was itself written in verse. No doubt like Boileau and his peers, Russian poets of the Silver Age deplored the bad verse their predecessors had written, considered it their duty to clean up Russian poetry-and succeeded magnificently.

If the situations in English and Russian poetry in the early twentieth century had grown (at last) largely similar, the same cannot be said of the next several decades. As this volume's introduction mentions, the Soviet period was not an easy time for literature. The impact of government literary bureaucracy and censorship, obligatory Socialist Realism, and all kinds of self-preserving moves by writers sent most poets back to more traditional genres and metrical forms; those who had experimented with unrhymed or slant-rhymed verse tended to leave those experiments in their past, perhaps retaining Mayakovskian "stair-step" format as a gesture toward the revolutionary avant-garde. (Some Russian poets, of course, did not self-preserve in these ways; look up the OBERIU, if you have not read them yet. Poetry was a surprisingly high-stakes game in the Soviet period.) Some of the more traditional-looking poetry of the Soviet era was still great—-the late Akhmatova, the late Pasternak, not to 
mention the work of younger poets - but it was no longer in step with prosodic and generic developments in England, France, or the countries of Central and Eastern Europe that were geographically nearer to Russia. The "freeze" imposed on the many Silver Age poets who were politically unacceptable meant that both their works and the innovations they embodied could not be part of public discourse; few Soviet readers had access to their work, and it was risky to be caught with a forbidden book while trying to enjoy that access, never mind to bring innovations into one's own poetry. In the late Soviet period, the cost of writing in different forms was not so high, but it still meant writing for an underground and self-publishing in samizdat. Russian poets write and publish today in all kinds of forms, but forms other than syllabo-tonic verse still feel innovative against that recent background; many significant poets continue to write in the forms that shaped the tastes and aesthetic responses of Soviet readers. Therefore, we would argue, many of the issues that translators of Russian poetry into English now face were shaped by the decades after the Silver Age, not by the Silver Age itself.

Besides the different political situations and the historical timing, two big additional reasons help explain why Russian and English poetry are different now: one is the arsenal of rhymes and perception of rhyme, and another is the different word length and stress patterns of the languages themselves, with their consequences for poetry written in those languages.

\section{Rhyme in Russian and English Poetry}

Neither Old Russian (Rusian) poetry nor Old English (Anglo-Saxon) poetry used rhyme; in both traditions rhyme came in "from outside," borrowed from other literary traditions and generally described with terms taken from Classical Greek via Latin in the Renaissance and beyond. The possibilities for rhyming became evident once poets (be they Chaucer or Lomonosov) began writing rhymed poetry and others followed them. It is certainly true that some Russian rhymes were already "tired" by the Golden Age; Pushkin made fun of the rhyme "morozy/rozy" - literally "frosts/roses," but translatable as "moon/ June"-in 1824-25, in the fourth chapter of his novel in verse Eugene Onegin. Nevertheless, Russian grammar and word forms still offer more possibilities for rhymes in Russian, with not only feminine rhymes (where the stressed, rhyming syllable is followed by another syllable that also fits the rhyme) but 
even dactylic and hyperdactylic rhymes (where the stressed syllable is followed by two or more syllables that also fit the rhyme). English poetry had shifted to using predominantly masculine rhymes by the seventeenth century, neglecting the longer rhymes. Due to shorter word length (about which more below), many exact rhymes in English are now hackneyed (though they live on in popular songs, rap music, and spoken word poetry, where moreover feminine rhyme sounds incisive and clever rather than merely amusing). It is telling that Mayakovsky's play with rhyme and meter closely resembles the work of Ogden Nash, a well-known comic poet writing in English. Both stretched the rules for verse composition to humorous effect for readers who were accustomed to versification that was essentially syllabo-tonic.

Word length and stress patterns conditioned the shift of English-language poetry away from strict metrical forms. The average length (in syllables) of a word in an ordinary prose text in English is a bit over one syllable, while the average length of a Russian word in an analogous text is over two syllables. English does have plenty of long words, but words of more than three syllables tend to have secondary stresses, and very long words will have more than one secondary stress. (Most of these long words are "twenty-five-cent words," which will also affect the stylistic level of a poem where they might be used.) Any Russian word — even a very long one (unless it compounds two words) has only one stress, and the many unstressed syllables in these words (which, again, are already longer on the average than English words) allow a skillful poet to write regular metrical verse (especially trimeter verse, fully represented in the Russian tradition by all three variants: dactyl, amphibrach, and anapest) more easily without becoming rhythmically monotonous. For more discussion of the differences in rhyme and word stress between English and Russian, see Vladimir Nabokov's famous article "Problems of Translation: Onegin in English." ${ }^{1}$ Nabokov took these difficulties as sufficient reason not to make a rhyming and scanning translation of Pushkin's Eugene Onegin.

An additional factor impacting all of this is the fondness of most English-language literary traditions for "domesticated" translations, discussed

1 Vladimir Nabokov, "Problems of Translation: Onegin in English," in The Translation Studies Reader, 3rd edition, ed. Lawrence Venuti (London and New York: Routledge, 2012), 113-125. 
in detail by Lawrence Venuti in his book The Translator's Invisibility. ${ }^{2}$ People who read poetry in English are often very fond of the rhymed, metered work of earlier generations, but those who read contemporary poets are used to poetry that signifies its aesthetic value in different ways. A translation that rhymes and scans can sound like bad Tennyson, and that might fit a late ninteenthcentury Russian poet like Nadson but most assuredly does not suit the best writers of the Silver Age. Readers accustomed to English-language poetry are likely to prefer verse that feels more like what most English-language poets are writing today - which is for the most part not rhyming, scanning poetry.

Some translations in this collection scrupulously reproduce the meter and (as much as possible) the rhyme scheme of the original poems. We have also included some very free translations, and then a number that shift between the two positions, drawn away from reproduction of meter and rhyme when those exigencies force too much padding, require too many syllables, or make it impossible to convey the meaning of the original. (Because we don't read a Russian poem just to enjoy it, right? We also want to see what these certified great poets are writing ABOUT.) More than one approach to formal equivalence can result in a meaningful translation, and we would argue that there is no "right way" to do it: different approaches to translation will get different results, each with its particular values. To close this brief discussion we offer several versions of a poem for the reader to compare. Reading multiple translations is the richest and most informative way to approach a poem from a foreign literature, and if you are drawn to any of the poems in this anthology we strongly recommend looking at multiple versions. Each will offer a particular angle or window on what the original does. This is one reason why we list the collections where you might find more translations of a particular poet, under each poet's individual selection of poems.

As you read the following versions of the same poem by Anna Akhmatova, you will notice that some are stricter in reproducing the rhyme and meter, while others are less strict. If you know Russian, you will see where the translators have kept unusual turns of phrase, or added new turns of meaning in pursuit of similar effects.

2 Lawrence Venuti, The Translator's Invisibility: A History of Translation, 2nd edition (London and New York: Routledge, 2008). 